\title{
PERANAN KOPERASI UNIT DESA DHARMA BHAKTI
}

\author{
Kaja \\ Fakultas Ilmu Sosial dan Ilmu Politik Universitas Kapuas Sintang \\ Email:kajaunka@gmail.com \\ Universitas Kapuas Sintang, Jl. Y.C. Oevang Oeray, No.92 Sintang Kalimantan Barat
}

\begin{abstract}
Abstrak :Peranan Koperasi mempunyai andil yang cukup besar dalam upaya meningkatkan ekonomi masyarakat sehingga koperasi sebagai sarana kesejahteraan masyarakat khususnya anggota, oleh karena itu, pengembangan koperasi memiliki peran utama yakni meningkatkan kesejahteraan anggota yang berpijak dari oleh dan untuk anggota koperasi. Dengan demikian peranan koperasi memperkuat perekonomian anggota, oleh karena itu, keberadaan koperasi memang di rasakan sangat bermanfaat sebagai sarana kesejahteraan anggota. Pemberdayaan anggota sudah dilaksanakan melalui pemberian pinjaman dan bimbingan teknis serta melalui pelayanan pendidikan dan motivasi salah satu syarat menjadi anggota Koperasi. Koperasi melakukan pembinaan dan penyuluhan bekerja sama dengan penyuluh pertanian lapangan (PPL), dalam memberikan bimbingan dan pendampingan serta pembinaan terhadap anggota secara teknis berkaitan dengan pengelolaan keuangan sehingga penggunaan keuangan lebih efektif dan efisien.
\end{abstract}

Kata Kunci : Peranan, Koperasi, anggota

Undang-Undang Republik Indonesia Nomor 17 Tahun 2012 tentang perkoperasian Undang-Undang ini di batalkan memicu pro dan kontra. Namun MK mempunyai alasan kuat, adapun alasan pembatalannya antara lain : (1) Hilangnya asas kekeluargaan dalam UndangUndang Nomor 17 Tahun 2012 (2) Terdapat banyak pasal yang kontradiksi satu sama lain, sehingga Undang- Undang Koperasi kembali pada Undang-Undang Nomor 25 Tahun 1992 Tentang Koperasi menegaskan bahwa pembangunan perekonomian nasional bertujuan untuk mewujudkan kesejahteraan masyarakat melalui pengelolaan sumber daya ekonomi maupun sumber daya alam yang tersedia dapat di manfaatkan untuk kepentingan dan kemakmuran rakyat berdasarkan asas kekeluargaan dalam rangka menciptakan masyarakat yang adil dan makmur berlandaskan Pancasila dan Undang-Undang Dasar Negara Republik Indonesia Tahun 1945.

Bertitik tolak dari pengertian di atas, maka pengembangan dan pemberdayaan masyarakat dalam rangka meningkatkan perekonomian nasional maka keberadaan koperasi sebagai fondasi perekonomian masyarakat dalam tatanan kebijakan ekonomi dapat menjadi soko guru perekonomian bangsa, yang mencerminkan prinsip koperasi sebagai wadah usaha bersama untuk memenuhi aspirasi dan kebutuhan ekonomi anggota sehingga tumbuh menjadi kuat, sehat, mandiri dan tangguh dalam menghadapi perkembangan ekonomi nasional dan global yang semakin dinamis dan penuh tantangan. Pembangunan ekonomi nasional bertujuan untuk mewujudkan kedaulatan politik dan ekonomi Indonesia melalui pengelolaan sumber daya ekonomi dalam suatu iklim pengembangan dan pemberdayaan koperasi yang memiliki peran strategis dalam tata ekonomi nasional berdasarkan asas kekeluargaan dan demokrasi ekonomi dalam rangka menciptakan masyarakat yang maju, adil dan makmur berlandaskan Pancasila dan UndangUndang Dasar Negara Republik Indonesia Tahun 1945. Pengembangan dan pemberdayaan Koperasi dalam suatu kebijakan Perkoperasian harus mencerminkan nilai dan perinsip koperasi sebagai wadah usaha bersama untuk memenuhi aspirasi dan kebutuhan ekonomian Anggota sehimgga tumbuh menjadi kuat, sehat, mandiri dan tangguh dalam menghadapi perkembangan ekonomi nasional dan global yang semakin dinamis dan penuh tantangan. Secara umum yang disebut koperasi adalah suatu badan usaha bersama yang bergerak dibidang perekonomian, beranggotakan orang perorang atau badan hukum koperasi atas dasar persamaan hak dan kewajiban dalam melakukan suatu usaha dibidang ekonomi. Koporasi mempunyai tujuan yang berorientasi pada pemenuhan kebutuhan dan mensejahterakan para anggotanya. Hal ini pula diikuti dengan kemajuan didunia usaha yang bergerak dibidang industri, perdagangan dan jasa yang ditawarkan kepada konsumen atau anggota koperasi.

Dengan demikian tujuan koperasi untuk meningkatkan kesejahteraan anggotanya melalui fasilitas pelayanan yang disediakan, seperti simpan pinjam, pembangian sisa hasil usaha dan santunan kepada anggotanya, serta berorientasi pada kesejahteraan anggota. Keberhsilan koperasi dapat diukur melalui berbagai pencapaian seperti: meningkatnya jumlah anggota, peningkatan aset dan jumlah modal usaha yang berasal dari simpanan sukarela semua anggota dan hasil usaha yang terus 
mengalami kenaikan. Oleh karena itu Koperasi Unit Desa memerlukan partisipasi dari seluruh masyarakat sebagai anggotanya, sebab koperasi bukan mengejar keuntungan yang menjadi prioritas tetapi lebih focus pada peningkatan kesejahteraan masyarakat. Melalui uraian tersebut bahwa, upaya meningkatkan kesejahteraan masyarakat dapat terwujud di desa melalui koperasi sangat penting, oleh karena itu pengurus, pengawas, manajemen koperasi harus berjalan bersama dan efektif dalam membuat kebijakan maupun keputusan, karena keberhasilan koperasi terutama dalam penganalisaan, perencanaan dan pelaksanaan program-program yang ditujukan untuk mencapai tujuan kesejahteraan masyarakat. Sejalan dengan hal tersebut maka Pemerintah mengarahkan dan mengembalikan posisi ekonomi Indonesia sesuai keinginan proklamator dengan isu ekonomi kerakyatan.

Sejalan dengan hal tersebut dan sesuai dengan tujuan koperasi untuk mensejahterakan masyarakat sehingga menempatkan koperasi sebagai motivator utama dalam menggerakan perekonomian masyarakat sesuai dengan amanat Undang-Undang Dasar 1945 pasal 33. Salah satu bentuk koperasi yang dikembangkan pemerintah bagi masyarakat yang selalu mengalami kekurangan modal, kekurangan motivasi dan kekurangan manajemen sehingga tujuan koperasi untuk kesejahteraan masyarakat tidak dapat berjalan sebagaimana yang di harapkan karena terdapat banyak kendala yang di alami oleh perkoperasian di Indonesia sekarang ini. Berdasarkan pengamatan pra-penelitian menunjukan bahwa masih terdapat anggapan negatif dari masyarakat berupa kehilangan kepercayaan terhadap koperasi, dengan alasan sering mengalami kerugian dan menjadi keuntungan pribadi bagi manejemen dan pengurus koperasi sehingga anggota sebagai pihak yang di rugikan. Kondisi ini tentunya akan berimplikasi terhadap perkembangan dan kemajuan koperasi, sehingga keberadaan koperasi saat ini harus berusaha mengembalikan kepercayaan masyarakat terhadap koperasi, serta meningkatkan perekonomian masyarakat pada umumnya dan anggota keperasi khususnya.

Dengan demikian, koperasi dikendalikan secara bersama seluruh anggota koperasi, karena setiap anggota memiliki hak suara yang sama dalam setiap keputusan yang di ambil, sedangkan pembagian sisa hasil usaha biasanya dihitung berdasarkan andil bersama. Selanjutnya Koperasi menurut Mohamad Hatta (Bapak Koperasi Indonesia) menjelaskan,"Koperasi adalah usaha bersama untuk memperbaiki nasib penghidupan ekonomi berdasarkan tolong-menolong. Semangat tolong-menolong tersebut didorong oleh keinginan memberi jasa kepada kawan berdasarkan seorang buat semua dan semua buat seorang." (http :// pengertiandasarkoperasi.blogspot.com). Menurut Undang-Undang Nomor 25 Tahun 1992 Koperasi adalah," badan usaha yang beranggotakan orangorang atau badan hukum koperasi, dengan berlandaskan kegiatannya berdasarkan prinsip koperasi sekaligus sebagai gerakan ekonomi rakyat yang berdasarkan atas azas kekeluargaan." Dengan demikian, koperasi adalah perkumpulan orangorang atau badan hukum yang bertujuan untuk kesejahteraan masyarakat secara bersama-sama sesuai dengan azas kekeluargaan dan gotongroyong. Selanjutnya Robert Owen (Sastraatmaja, 2005 : 50-51) mengatakan," bahwa koperasi adalah obat manjur untuk memunculkan kesejahteraan, dengan gerakan koperasi inilah kemiskinan mesti dihapuskan, begitupun kemelaratan, itulah sebabnya mengapa koperasi sering di sebut sebagai alat ampuh dalam pembangunan di Indonesia." Sesuai dengan pendapat ahli di atas, jelas bukan hal yang cukup mudah untuk di selesaikan sehingga dapat menjadikan masyarakat sejahtera, pemerintah harus berupaya mengembalikan citra koperasi ke rel yang seharusnya, rupanya tidak cukup hanya dengan sekadar hasrat politik saja, namun harus juga di barengi dengan tindakan politik yang mendukung.

Menurut Mohammad Hatta (Feryanto 2010 : 130) Koperasi Koperasi di Indonesia berdasarkan prinsip keanggotaan bersifat suka rela, keanggotaan terbuka, identitas sebagai pemilik dan pelanggan, manajemen pengawasan dilaksanakan secara demokratis, keadalah,"Usaha bersama untuk memperbaiki nasib penghidupan ekonomi berdasarkan semangat tolong-menolong. Semangat tolong-menolong tersebut di dorong oleh keinginan memberi jasa kepada sesama berdasarkan seorang buat semua dan semua buat seorang. Melalui semangat tersebut berarti menjadi anggota koperasi adalah keinginan untuk saling menolong satu dengan yang lainnya dan di dalamnya tidak ada unsur pemaksaan tetapi di dasarkan atas kemauan dan kerelaan diri sendiri untuk meningkatkan kesejahteraan bersama melalui usaha gotongroyong. Selanjutnya koperasi dalam melakukan pembagian sisa hasil usaha kepada anggota dilakukan secara adil tanpa ada perbedaan serta dalam penyelenggaraan pendidikan kepada anggota dengan prinsip-prinsip anggota serta netral terhadap politik dan agama.

Koperasi merupakan organisasi non profit yang dapat mengumpulkan serta mempersatukan kelompok-kelompok atau pun perkumpulan dari orang-orang yang memiliki tujuan yang sama tanpa campur tangan pihak lain, koperasi sampai saat ini belum banyak yang mampu bersaing dalam pasar bebas. Koperasi merupakan bentuk kelembagaan formal yang memiliki jaringan sangat luas bersifat internasional, oleh karena itu jika koperasi dilaksanakan secara professional sudah barang tentu mampu bersaing dengan pasar global, hal ini menuntut adanya perhatian semua masyarakat mamupun pemerintah agar sadar memaksimalkan fungsi koperasi, namun demikian, kelemahan dari 
koperasi adalah faktor internalnya sendiri yang membatasi partisipasi anggota, karena koperasi menghendaki homogenitas anggota terutama dari aspek kepentingannya terhadap koperasi. Anggaran Dasar (AD) koperasi merupakan cerminan dari kepentingan anggota, oleh karena itu AD diseragamkan (oleh instansi pemerintah), hal ini berarti kepentingan anggota juga sama, dengan demikian, AD yang disusun sesuai dengan peraturan perundang-undangan yang berlaku, karena berapapun besarnya biaya pembinaan yang dikeluarkan oleh pemerintah, dalam kampanye gerakan koperasi serta tingginya dedikasi dari pengurus, badan pengawas dan manager tidak akan membuat sebuah koperasi berkembang tanpa adanya peran aktif dari para anggotanya. Kedudukan anggota dalam koperasi sangat penting karena anggota sebagai pemilik dan juga merupakan pelanggan bagi koperasi yang menentukan maju dan mundurnya koperasi. Dengan demikian di dalam koperasi tidak ada yang merasa lebih dominan, karena koperasi merupakan milik bersama.

Koperasi tidak dapat berjalan efektif jika tidak di dukung oleh anggota dalam memenuhi kewajiban-kewajibannya, yaitu membayar simpanan pokok, simpanan wajib, dan simpanan sukarela, peranan dalam pengambilan keputusan dan pengawasan memerlukan keterlibatan anggota. Kurangnya peranan anggota dalam kehidupan berkoperasi akan mengakibatkan koperasi tidak dapat menjadi koperasi yang mandiri. Oleh karena itu koperasi adalah organisasi ekonomi yang dimiliki dan di operasionalkan oleh orang-orang yang memiliki kepentingan bersama, koperasi juga berlandaskan prinsip gerakan ekonomi rakyat yang berdasarkan asas kekeluargaan. Namun demikian, tujuan koperasi memajukan kesejahteraan ekonomi anggota pada khususnya dan masyarakat pada umumnya serta ikut membangun tatanan perekonomian nasional dalam rangka mewujudkan yang maju, adil dan makmur berladaskan pancasila dan Undang-Undang Dasar 1945. Pemberdayaan masyarakat bertujuan menumbuhkan dan meningkatkan kemampuan usaha kecil dalam pembentukan produk nasional, perluasan kesempatan kerja, meningkatkan ekspor serta peningkatan dan pemerataan pendapatan untuk mewujudkan dirinya sebagai dasar memperkokoh perekonomian nasional. Koperasi dalam konteks demokrasi ekonomi merupakan serangkaian kegiatan perekonomian yang meliputi produksi dan konsumsi yang dilakukan oleh semua warga masyarakat, untuk masyarakat, pengelolaan dan pengawasannya dilakukan sendiri oleh masyarakat, dengan kata lain prinsip ekonomi kerakyatan dan demokrasi ekonomi secara nyata tercermin dalam bentuk koperasi yang berasaskan kekeluargaan.
Sejalan dengan hal tersebut maka Koperasi Unit Desa merupakan kepentingan ekonomi rakyat utamanya kelompok masyarakat yang berada pada aras ekonomi kelas bawah seperti buruh, petani, nelayan, pedagang kecil dan lain-lainnya, akan mudah diperjuangkan kepentingan ekonominya melalui koperasi, inilah sebenarnya yang menjadi alasan utama pentingnya pemberdayaan koperasi. Ekonomi kerakyatan sesuai dengan pancasila khususnya sila ke-4 yang menekankan pada sifat demokratis sistem ekonomo Indonesia, produksi tidak hanya dikerjakan oleh sebagian warga tetapi oleh semua warga masyarakat, dan hasilnya dibagi kepada semua anggota masyarakat secara adil dan merata (sesuai penjelasan pasal 33 UUD 1945). Sesuai dengan hal tersebut di atas, maka perekonomian khususnya masyarakat akan menuju kesejahteraan yang baik tindakan kegiatan ekonomi yang sangat cocok dilakukan adalah Koperasi Unit Desa (KUD), karena KUD kegiatannya membina dan mengadakan pembinaan bagi anggota koperasi, dengan demikian KUD pada hakikatnya adalah pemberdayaan masyarakat.

Koperasi berperanan menguatkan perekonomian masyarakat sebagai dasar dan ketahanan perekonomian nasional dengan koperasi sebagai panutannya, melalui koperasi dapat memperkukuh perekonomian karena koperasi berperan untuk mensejahterakan masyarakat sehingga koperasi juga merupakan fondasi ekonomi masyarakat desa. Koperasi Unit Desa (KUD) adalah koperasi yang ada di desa, koperasi unit desa sama dengan koperasi lain yaitu kepunyaan masyarakat oleh masyarakat dan untuk masyarakat, koperasi unit desa daerah kerjanya hanya satu desa dengan alasan memudahkan, selain daerah administratif pemerintah desa merupakan lingkungan sosial sekitar desa sehingga rasa kekeluargaan di antara sesame penduduk sangat baik, karena merasa warga satu lingkungan. Oleh karena itu, akan mudah pula hubungan antara anggota koperasi di dalam desa hubungan ini sangat penting bagi koperasi, dengan demikian koperasi unit desa merupakan fondasi ekonomi bagi masyarakat desa.

Menurut Sastraatmaja ( $1985: 61$ ) menjelaskan bahwa,'Koperasi desa itu merupakan bagian dari koperasi desa, jadi bukanlah beberapa koperasi bergabung, jadi usaha apa yang harus didahulukan untuk dapat memenuhi kebutuhan, biasanya tergantung kepada kepentingannya, dalam hal ini adalah anggota." Dengan demikian koperasi unit desa merupakan penyanggah ekonomi masyarakat desa atau dengan kata lain koperasi umumnya sebagai fondasi ekonomi masyakat Indonesia, sehingga kemajuan koperasi harus diperjuangkan bersama-sama oleh anggota koperasi. Menurut Damanik (Mubyarto, 2001 : 225) 
Koperasi tidak lain merupakan satu alat perjuangan. Sebagai alat perjuangan koperasi akan maju mencapai sukses apabila terus-menerus diperjuangkan oleh anggota-anggota gerakan." Selanjutnya sesuai dengan pendapat tersebut koperasi merupakan alat untuk mencapai kesejahteraan masyarakat yang sangat mendasar, sehingga peranan koperasi sebagai fondasi ekonomi masyarakat. Dengan demikian koperasi harus diperjuangkan dan dilaksanakan oleh masyarakat sebagai urat nadi perekonomian masyarakat desa maupun seluruh masyarakat Indonesia sesuai dengan UUD 1945 pasal 33.

Menurut Ananda Santoso (2015 : 170) dalam Kamus Lengkap Bahasa Indonesia bahwa,"Fondasi adalah dasar sebuah bangunan." Sedangkan menurut Poerwadarminta Fondasi berarti dasar bangunan yang kuat, biasanya (terdapat) di bawah permukaan tanah tempat bangunan itu didirikan, fundamen." Berdasarkan definisi tersebut maka fondasi ekonomi merupakan tolok ukur kemajuan suatu bangsa dan Negara, sebab pertumbuhan ekonomi sangat penting artinya bagi suatu bangsa, sebab suatu Negara tidak dapat melaksanakan pembangunan di sektor lain jika tidak di dukung oleh perekonomian yang memadai. Fondasi perekonomian yang kuat mutlak di perlukan untuk kelangsungan pembangunan ekonomi, untuk memperkuat fondasi perekonomian Indonesia harus focus membenahi industri nasional, sehingga ketergantungan pada asing semakin berkurang. Langkah pemerintah dalam menggerakan koperasi itu sudah tepat dalam memperkuat usaha fondasi perekonomian bangsa. Selanjutnya dengan perekonomian yang kuat maka kesejahteraan masyarakatnya akan terjamin, sehingga tingkat kriminalitas sebagian besar di sebabkan karena faktor ekonomi yang menurun. Dengan demikian, koperasi sebagai gerakan ekonomi masyarakat berperan serta mewujudkan masyarakat yang maju, adil makmur berlandaskan Pancasila dan Undang-Undang Dasar 1945 dalam tatanan perekonomian nasional yang disusun sebagai usaha bersama berdasarkan atas asas kekeluargaan dan demokrasi ekonomi. Koperasi berperan juga sebaga fondasi ekonomi, hal tersebut di sebabkan karena koperasi unit desa dapat menolong ekonomi masyarakat desa, serta menjadi perkumpulan masyarakat desa dalam memberdayakan dirinya melalui usaha simpan pinjam untuk melakukan usaha dan kesempatan berusaha bagi masyarakat desa, dengan demikian maka perekonomian masyarakat desa lebih meningkatterutama masyarakat dapat memenuhi kebutuhan mendasar dalam kehidupannya.

Koperasi sebagai fondasi ekonomi rakyat, namun demikian bantuan pemerintah terhadap koperasi sangat minim, selain itu lembaga yang terkait dengan koperasi tidak di libatkan ketika ingin membuat konsep pemberdayaan koperasi. Koperasi bertujuan memajukan kesejahteraan anggota pada khususnya dan masyarakat pada umumnya serta ikut membangun tatanan perekonomian nasional dalam rangka mewujudkan masyarakat yang maju, adil, dan makmur berlandaskan pancasila dan UUD 1945. Pemberdayaan Usaha Kecil dan Menengah dalam produk nasional, perluasan kesempatan kerja dan berusaha semuanya bertujuan memperkukuh struktur perekonomian nasional. Sejalan dengan hal tersebut peranan koperasi juga sebagai soko guru perekonomian Indonesia, makna dari istilah soko guru tersebut dapat di artikan bahwa koperasi sebagai pilar atau penyangga utama atau tulang punggung perekonomian.

Undang-Undang Perkoperasian Nomor 25 Tahun 1992 menjelaskan bahwa landasan koperasi Indonesia meliputi : (1) Landasan Idiil Pancasila, (2) landasan struktural UUD 1945, (3) landasan gerak pasal 33 ayat (1) UUD 1945 (4) landasan mental kesetiakawanan dan kesadaran pribadi. Di Indonesia telah di buat berdasarkan UndangUndang Perkoperasian bahwa Prinsip koperasi adalah : (1) Keanggotaan bersifat suka rela dan terbuka (2) Pengelolaan dilakukan secara demokrasi (3) Pembagian SHU dilakukan secara adil sesuai dengan jasa usaha masing-masing anggota (4) Pemberian balas jasa yang terbatas terhadap modal (5) Kemandirian, Pendidikan perkoperasian (6) Kerja sama antar koperasi. Menurut Pasal 1 angka 1 Undang-Undang Nomor 17 Tahun 2012 tentang Perkoperasian bahwa yang dimaksud koperasi adalah: "badan hukum yang didirikan oleh orang perseorangan atau badan hukum koperasi, dengan pemisahan kekayaan para anggotanya sebagai modal untuk menjalankan usaha, yang memenuhi aspirasi dan kebutuhan bersama di bidang ekonomi, sosial, dan budaya sesuai dengan nilai dan prinsip koperasi."

Rudianto (2006:2) menyatakan bahwa : "koperasi adalah badan usaha yang mengorganisir pemanfaatan dan pendayagunaan sumber daya ekonomi para anggotanya atas dasar prinsip-prinsip koperasi dan kaidah usaha ekonomi untuk meningkatkan taraf hidup anggota pada khususnya dan masyarakat daerah pada umumnya." Dengan demikian koperasi merupakan ekonomi rakyat dan sokoguru perekonomian nasional, sehingga keberadaan koperasi di Indonesia menjadi penopang dan penguat ekonomi masyarakat. Koperasi sebagai bentuk badan hukum di Indonesia memiliki 4 (empat) macam jenis koperasi sebagaimana dinyatakan dalam Pasal 83 dan Pasal 84 UndangUndang Nomor 17 Tahun 2012 tentang Perkoperasian bahwa jenis-jenis koperasi meliputi : Koperasi Konsumen, yaitu koperasi yang menyelenggarakan kegiatan usaha pelayanan di 
bidang penyediaan barang kebutuhan anggota dan non-anggota. Koperasi Produsen, yaitu koperasi yang menyelenggarakan kegiatan usaha pelayanan di bidang pengadaan sarana produksi dan pemasaran produksi yang dihasilkan anggota kepada anggota dan non-anggota. Koperasi Jasa, yaitu koperasi yang menyelenggarakan kegiatan usaha pelayanan jasa non-simpan pinjam yang diperlukan oleh anggota dan non-anggota. Koperasi Simpan Pinjam, yaitu koperasi yang menjalankan usaha simpan pinjam sebagai satu-satunya usaha yang melayani anggota. Dari 4 (empat) macam jenis koperasi di atas mengartikan bahwa tidak semua koperasi melayani kredit namun hanya koperasi simpan pinjam yang merupakan jenis koperasi yang bergerak di bidang pelayanan kredit yang artinya bahwa koperasi itu menerima dana/uang dari para anggota untuk di simpan serta memberikan pinjaman berupa kredit uang kepada anggota yang membutuhkan. Melalui pinjaman tersebut anggota koperasi dapat meningkatkan kebutuhan dasarnya atau dapat memenuhi kebutuhan primernya sehingga koperasi menjadi fondasi ekonomi masyarakat.

Koperasi juga sebagai Sarana Kesejahteraan ekonomi masyarakat Sesuai dengan tujuannya meningkatkan kesejahteraan masyarakat melalui pendampingan pembinaan usaha pada anggota serta pemberdayaan anggota koperasi. Dalam pelaksanaan program Koperasi Unit Desa tidak terlepas dari fasilitas yang dipergunakan dalam melaksanakan aktivitas-aktivitas untuk mencapai tujuan koperasi. Demikian pula dalam proses kegiatan pelayanan koperasi, terlebih dengan kemajuan teknologi dewasa ini, manusia bukan lagi sebagai pembantu bagi mesin seperti pada masa sebelum revolusi industri, tetapi sebaliknya mesin telah berubah kedudukannya sebagai pembantu manusia. Menurut Muhroji (2002:55) mengatakan bahwa"Fasilitas sendiri dapat diartikan sebagai segala sesuatu yang dapat memudahkan dan melancarkan pelaksanaan suatu kegiatan dalam rangka mencapai tujuan, Fasilitas yang disediakan mampu menambah kesenangan dan meningkatkan semangat kerja para karyawan. Fungsi fasilitas menunjang pelayanan kepada anggota agar semua kegiatan tersebut dapat berjalan dengan efektif dan efisien. Dengan demikian, fasilitas yang baik, merupakan sumber kekuatan organisasi dan mewujudkan karyawan semakin rajin serta akan tekun bekerja dengan fasilitas yang ada.

Menurut Boediono (2015 : 101) dalam Kamus Besar Bahasa Indonesia, bahwa, "Kesejahteraan sosial dapat berarti kesejahteraan sebuah masyarakat, penyediaan pelayanan sosial di berbagai bidang untuk keuntungan individu, kesejahteraan sosial merupakan keadaan dimana seorang merasa nyaman, tentram, bahagia serta dapat memenuhi kebutuhan hidupnya." Dengan demikian kesejahteraan menjadi tujuan yang ingin di capai oleh manusia sehingga berbagai macam organisasi maupun profesi melakukan aktivitas dalam rangka mewujudkannya, namun demikian kesejahteraan tidak dapat di sama ratakan karena berkaitan dengan tingkat kepuasan individu. Pelaksanaan tugas dan fungsinya dengan baik tidak hanya pengelolaan keuangan yang menjadi faktor penentu akan tetapi ketersediaan sarana dan prasarana juga diperlukan. Sarana dan prasarana adalah ketersediaan peralatan yang diperlukan untuk mendukung dalam proses pencapaian tujuan. Menurut Handoko (2002:97) adalah setiap benda atau alat yang dapat dipergunakan untuk memperlancar pekerjaan atau kegiatan Pemerintah Daerah seperti alat-alat kantor, alat-alat komunikasi, dan transportasi. Ini diperlukan karena organisasi pemerintah yang serba kompleks memerlukan alatalat yang serba praktis dan efisien. Peralatan yang ada disesuaikan dengan kebutuhan dan kondisi keuangan, serta kecakapan aparatur yang menggunakannya. Menurut Widjaja (2002 : 82) “ manusia merupakan faktor utama dalam sistim manajemen, karena manusia merupakan sumbu utama dalam pelaksanaan manajemen itu sendiri, sarana tidak kalah pentingnya dalam ketatalaksanaan manajemen yaitu alat tukar atau uang/modal dan diikuti oleh sarana-sarana lain berupa materi, mesin, metode dan pasar ". Sejalan dengan pendapat tersebut kesejahteraan masyarakat akan tercapai harus di dukung oleh sumber daya manusia maupun sumber daya alam yang dapat di manfaat dengan sebesar-besarnya bagi kemakmuran rakyat sesuai dengan amanat UUD 1945 pasal 33. Sarana dan prasarana koperasi seperti tersedianya produk simpan pinjam, simpanan suka rela anggota serta tersedianya kantor dan kelengkapan lainnya penting karena di gunakan untuk melaksanakan kegiatan ketatausahaan/ administrasi kantor terutama berkaitan dengan pengarsipan maupun pembukuan. Sarana yang di maksud tersebut untuk memperlancar kegiatan sehingga dalam proses pelayanan pada anggota tidak mengalami kendala.

Adapun fungsi peralatan kantor menurut Gie (2005:256) adalah : “a). mempertinggi kemampuan pegawai yang mempergunakan alatalat tersebut, b). memperkecil pengorbanan waktu, tenaga dan biaya, c). mempertinggi kualitas dan kuantitas hasil kerja dan d). mempertinggi kelangsungan kesejahteraan kerja." Dalam hubungan dengan pelaksanaan pemberian kredit koperasi, maka sarana dan prasarana perkantoran ini sangat berperan dalam meningkatkan kualitas dan kuantitas kerja sehingga pelaksanaan kerja semakin efektif dan efisien dan akhirnya bermuara pada hasil kerja yang memuaskan seperti yang telah ditetapkan dalam perencanaan kerja. Dengan demikian adanya sarana prasarana kerja ini diharapkan pelaksanaan pemberian kredit koperasi 
semakin cepat dan mudah dalam memberikan pelayanan kepada anggota. Sejalan dengan hal tersebut di atas dalam rangka mengembangkan potensi/pemberdayaan masyarakat, koperasi idealnya harus dimulai dengan asas dan prinsipprinsip koperasi. Asas gotong royong dan kekeluargaan yang dianut oleh koperasi sudah secara tegas dinyatakan dalam amanat konstitusi. Menurut Nasution Muslimin, (2001:45) bahwa "prinsip-prinsip dasar koperasi sebagian besar sudah sesuai dengan kondisi sosial ekonomi masyarakat di Indonesia sekarang ini (yang diwarnai dengan ketimpangan dan banyaknya jumlah orang miskin dan pengangguran)"

Budiman (2002 : 332) mengatakan" Pemberdayaan sebagai proses mengembangkan, memandirikan, menswadayakan, memperkuat posisi tawar menawar masyarakat lapisan bawah terhadap kekuatan- kekuatan penekan di segala bidang dan sektor kehidupan masyarakat. Oleh karena itu, pemberdayaan dimakna dalam konteks meningkatkan posisi dan harkat, derajat serta martabat manusia (masyarakat). Sejalan dengan pendapat ahli tersebut maka koperasi unit desa harus mampu memberdayakan dirinya dan menolong dirinya sendiri sehingga lebih mengutamakan kemampuan dan swadaya anggota koperasi itu sendiri melalui simpanan suka rela anggota tentunya dalam pengelolaannya melalui bimbingan dan arahan dari pengurus maupun manajemen koperasi. Dengan demikian, anggota koperasi sebagai subjek (agen pelaksana) yang berusaha secara mandiri tentunya ada pendampingan dari manajemen koperasi. Handayani (1999 : 130) mengatakan, "Pemberdayaan adalah proses memfasilitasi warga masyarakat secara bersama-sama pada sebuah kepentingan bersama atau urusan secara kolektif dapat mengidentifikasi sasaran, mengumpulkan sumber daya, mengerahkan suatu kampanye aksi dan oleh karena itu membantu menyusun kembali kekuatan dalam komunitas." Dengan demikian anggota koperasi yang mandiri dalam pengelolaan keuangan menentukan arah dan tujuannya secara individu, tetapi sejalan dengan tujuan koperasi di antaranya adalah untuk kesejahteraan masyarakat. Koperas unit desa sifatnya terbuka dalam menerima anggota tidak membedakan latar belakang dan pengalaman seseorang yang penting memiliki kesamaan tujuan.

Dengan demikian, anggota koperasi terbentuk dari kesadaran masing-masing individu untuk menjadi anggotanya, hal ini berarti bahwa terbukanya ruang dan kapasitas untuk masyarakat menjadi anggota koperasi dan melaksanakan kerja sama untuk memajukan koperasi di samping menjalankan usaha individu sesuai dengan tujuan koperasi, dengan menggunakan potensi yang dimiliki oleh anggota itu sendiri, sehingga kesejahteraan dapat di capai oleh anggota koperasi.
Pemberdayaan anggota koperasi merupakan alternatif dalam memandirikan masyarakat bergerak dalam bidang ekonomi, oleh karena itu, masyarakat menempati posisi utama yang memulai, mengelola dan menikmati hasil koperasi itu sendiri. Negara sebagai fasilitator dan membuka ruang yang kondusif bagi tumbuh dan berkembangnya partisipasi dan swadaya anggotanya. Selanjutnya Pemberdayaan masyarakat Desa menurut UndangUndang Nomor 6 Tahun 2014 Tentang Desa. Dengan demikian Undang-Undang tersebut mengisyaratkan agar masyarakat dapat mengembangkan kemandirian dan kesejahteraan masyarakat dengan meningkatkan pengetahuan, sikap, keterampilan, perilaku, kemampuan, kesadaran serta memanfaatkan sumber daya melalui penetapan kebijakan program, kegiatan dan pendampingan yang sesuai dengan esensi masalah dan prioritas kebutuhan masyarakat Desa. Sejalan dengan Undang-Undang tersebut maka Koperasi Unit Desa (KUD) merupakan usaha yang dilakukan untuk menciptakan kemandirian dalam meningkatkan kesejahteraan masyarakat sesuai dengan peranan koperasi.

Robin (1996: 45) menjelaskan bahwa" pemberdayaan mengandung tiga komponen penting yaitu (1) multidimensi, yang berarti terjadi dalam aspek sosiologi, psikologi, ekonomi, dan dimensi yang lain; (2) sosial artinya pemberdayaan hanya terjadi jika ada hubungan (relationship) dengan yang lain; dan (3) proses, artinya pemberdayaan merupakan suatu perjalanan yang mengandung dimensi waktu." Dengan demikian dapat digambarkan bahwa pemberdayaan masyarakat terjadi dalam setiap aspek kehidupan, dan selalu melibatkan masyarakat, dan merupakan suatu proses yang membutuhkan waktu. Bertitik tolak dari pendapat ahli di atas, pemberdayaan mengarahkan orang lain untuk mampu meningkatkan ketrampilan sampai seseorang termotivasi untuk ambil tidakan meningkatkan kesejahteraannya sendiri melalui koperasi. Menurut Kretner (dalam Robin 1996:68) "Pemberdayaan berarti pembagian kekuasaan yang adil (equitable Sharing of power) sehingga meningkatkan kesadaran seseorang untuk bekerja secara optimal". Dengan demikian, pemberdayaan merupakan suatu kondisi yang memungkinkan orang merasa mampu, memiliki daya untuk berinisiatif dan mampu melaksanakan tugas serta memberikan kekuatan bagi motivasi diri masyarakat desa sebagian besar mata pencaharian adalah pertanian sehingga perlu ada perkumpulan atau wadah yang dapat memberikan peningkatan keterampilan masyarakat, oleh karena itu, keberadaan koperasi unit desa sangat penting artinya bagi masyarakat desa sehingga perlu perhatian dari semua pihak untuk mengembangkannya terutama instansi yang berkaitan dengan perkoperasian, terutama alat atau fasilitas yang dibutuhkan perlu bantuan dari pemerintah. 
Selanjutnya Subejo dan Supriyanto (2004 : 14) memaknai "Pemberdayaan masyarakat sebagai upaya yang disengaja untuk memfasilitasi masyarakat lokal yang dimiliki melalui colletive action dan networking sehingga pada akhirnya mereka memiliki kemampuan dan kemandirian secara ekonomi, ekologi, dan sosial. Oleh karena itu pemberdayaan menciptakan masyarakat mandiri dan sanggup menghidupi dirinya serta dapat meningkatkan kesejahteraan hidupnya yang layak. Selanjutnya Koperasi menurut Soedjono (2000 : 34), seorang pakar koperasi mendefinisikan koperasi sebagai: "perkumpulan otonom dari orangorang yang bersatu secara sukarela untuk memenuhi kebutuhan-kebutuhan dan aspirasi ekonomi, sosial dan budaya bersama melalui perusahaan yang mereka miliki bersama dan mereka kendalikan secara demokratis". Koperasi dalam pelaksanaannya tidak terlepas dari unsur-unsur koperasi, unsur koperasi yang di maksud menurut Feryanto (2010: 131) adalah : (1) Koperasi adalah badan usaha, (b) Koperasi adalah kumpulan orangorang dan atau badan-badan hukum koperasi, (c) Koperasi Indonesia merupakan koperasi yang bekerja berdasarkan prinsip-prinsip koperasi, (d) Koperasi Indonesia adalah gerakan ekonomi rakyat, (e) Koperasi Indonesia berasaskan kekeluargaan.

Berdasarkan unsur-unsur tersebut maka pasal 33 UUD 1945 di dalamnya terkandung unsurunsur pokok yaitu : demokrasi, mengutamakan kemakmuran masyarakat, usaha bersama atas asas kekeluargaan, dan penguasaan serta pengelolaan cabang-cabang produksi, bumi dan air dan kekayaan alam Indonesia. Selanjutnya dasar demokrasi ekonomi atau keadilan social telah tersimpul di dalam istilah kerakyatan. Dengan demikian kemakmuran rakyat dalam arti kata sepenuhnya dapat di capai melalui usaha kerja sama pemerintah maupun swasta dan seluruh masyarakat Indonesia.

\section{METODE PENELITIAN}

Jenis Penelitian yang digunakan adalah penelitian deskriptif, menurut Kartiwa $(2015: 21)$ metode deskriptif adalah "Penelitian yang menjelaskan sesuatu yang menjadi sasaran penelitian secara mendalam. Artinya penelitian tersebut dilakukan untuk mengungkapkan segala sesuatu atau berbagai aspek dari sasaran penelitiannya. Penelitian ini memberikan gambaran atau melukiskan fakta sebagaimana adanya dilapangan secara objektif mengenai persoalan yang diteliti. Oleh karena itu metode deskriptif adalah prosedur pemecahan masalah yang diselidiki dengan menggambarkan/melukiskan keadaan subjek/objek penelitian pada saat sekarang berdasarkan faktafakta yang tampak atau sebagaimana adanya. Metode dalam penelitian ini adalah metode deskriptif, metode deskriptif tidak hanya sekedar terbatas pada penemuan fakta seadanya, tetapi di analisis menggunakan data secara kualitatif dengan menginteprestasikan fakta-fakta atau data-data secara cermat dan teliti yang berkaitan dengan tujuan penelitian terutama sesuai dengan keperluan penelitian dalam rangka memberikan jawaban atau solusi permasalahan yang terjadi dilapangan yang berkaitan dengan Peranan Koperasi Unit Desa Dharma Bhakti dalam meningkatkan perekonomian masyarakat Desa Binjai Hilir Kecamatan Binjai Hulu Kabupaten Sintang. Subjek penelitian ini ditentukan terlebih dahulu dengan alasan karena yang bersangkutan mengetahui serta memahami persoalan yang diteliti sehingga dipilih menjadi subjek penelitian. Menurut Moleong (2000:245) “ yang dipilih dengan pertimbangan yang bersangkutan menguasai persoalan dan informasi yang sedang di teliti. Adapun yang menjadi subjek penelitian ini adalah sebagai berikut: Ketua pengurus KUD, Manager KUD, Pengawas KUD, Anggota KUD. Teknik yang digunakan dalam pengumpulan data adalah Wawancara

Observasi, Studi dokumentasi. Menurut Nasution (2001: 43) bahwa "wawancara yang dilakukan adalah wawancara yang bersifat terbuka dan tidak terstruktur." Sesuai dengan tekhnik penelitian di atas, maka alat pengumpulan data juga sebagai faktor penunjang dalam mendapatkan data dan informasi. Adapun alat yang digunakan dalam pengumpulan data adalah : Pedoman wawancara, merupakan daftar pertanyaan yang terarah yang diajukan langsung kepada subjek penelitian atau informan dalam rangka memperoleh data dan informasi secara lebih mendalam. Pedoman observasi, Menurut Faisal (2001:52), "pengamatan adalah pengumpulan data yang dilakukan dengan cara penginderaan langsung terhadap suatu benda, kondisi, situasi, proses atau prilaku". Teknik analisis data dalam penelitian ini menggunakan deskriptif data, yaitu data mentah yang telah terkumpul kemudian dideskripsikan dan digeneralisasikan serta ditarik kesimpulan secara kualitatif. Analisis data adalah penyederhanaan data ke dalam bentuk yang lebih mudah dibaca dan diinterpretasikan sehingga mudah untuk memahaminya data yang berkaitan dengan penelitian. Selanjutnya analisis umumnya menggunakan data yang berasal dari pertanyaanpertanyaan terbuka dari hasil wawancara.Lokasi penelitian ini dilakukan di Koperasi Unit Desa Dharma Bhakti Desa Binjai Hilir Kecamatan Binjai Hulu Kabupaten Sintang. Adapun yang menjadi alasan penelitian ini adalah : Secara Metodologis dapat menyediakan data yang diperlukan serta sebagai pemberi informasi dan sumber informasi serta dapat di jangkau oleh peneliti khususnya yang berkaitan dengan Koperasi Unit Desa Dharma Bhakti di Desa Bijai Hulu. Secara Praktis bahwa Koperasi Unit Desa dapat meningkatkan kesejahteraan masyarakat maupun dapat berperan sebagai fondasi ekonomi masyarakat, namun demikian koperasi Unit Desa Dharma Bhakti belum 
berjalan sebagaimana yang di harapkan, sehingga menarik untuk diteliti.

\section{HASIL PENELITIAN DAN PEMBAHASAN}

Desa Binjai Hilir adalah sebuah desa yang terletak di Kecamatan Binjai Hulu Kabupaten Sintang, jarak desa tersebut dengan pusat Pemerintahan Kecamatan kurang lebih $5 \mathrm{~km}$ sementara untuk menuju ke Kabupaten dari Desa Binjai Hilir dapat di tempuh dengan jarak kurang lebih $30 \mathrm{~km}$ melalui transfortasi darat, tetapi dapat juga di tempuh dengan kendaraan air (sungai) tetapi akhir-akhir ini trasfortasi melalui sungai jarang digunakan hal ini di sebabkan melalui darat lebih cepat daripada melalui sungai. Selain itu masyarakat desa Binjai Hulu lebih banyak menggunakan sepeda motor atau kendaraan roda dua, walaupun dilihat dari kondisi jalan memang rusak parah. Desa Binjai Hilir terdiri dari 4 (empat) dusun yaitu Dusun Suka Maju, Dusun Suka Damai, Dusun Suka Mulya, dan Dusun Suka Jaya serta terdiri dari 12 RT dan $6 \mathrm{RW}$ luas wilayah $3025 \mathrm{~km}$. Wilayah desa Binjai Hilir terdapat lahan persawahan, perkebunan dan pemukiman penduduk, namun dalam rincian penggunaan lahan secara rinci mengenai luas penggunaan masing-masing lahan tersebut belum ada. Luas tanah kas desa 25,6 km luas tanah yang bersertifikat 820 buah $(7.231 .161 \mathrm{Ha})$.

Sementara dalam penyelenggaraan Pemerintahan Desa sehari-hari, Pemerintahan Desa dibantu oleh lembaga kemasyarakatan antara lain PKK Desa, Lembaga Adat dan organisasi kemasyarakatan lainnya.

Selanjutnya mengenai batasa wilayah Desa Binjai Hilir berbatasan dengan beberapa desa adalah : Sebelah Utara berbatasan dengan Desa Sungai Risap, Sebelah Selatan berbatasan dengan Desa Teluk Kelansam, Sebelah Barat berbatasan dengan Desa Telaga Dua, Sebelah Timur berbatasan dengan Desa Binjai Hulu. Desa Binjai Hilir merupakan bagian dari Pemerintah Kabupaten Sintang memiliki iklim seperti umumnya wilayah Kalimantan Barat lainnya memiliki iklim tropis dengan dua musim, yaitu musim hujan dan musim kemarau, beberapa tahun lalu musim kemarau dan hujan dapat diprediksi sehingga bagi petani itu sangat mudah dalam membakar ladang, tetapi akhir-akhir ini sulit diketahui musimnya karena yang terjadi sekarang yang seharusnya musim kemarau tetapi justru sebaliknya musim hujan jadi cuaca saat ini tidak menentu, sehingga petani sulit untuk memprediksinya. Keadaan Penduduk Berdasarkan data yang penulis ambil dari data monografi desa Binjai Hilir di kantor Desa bahwa Penduduk Desa Binjai Hilir pada bulan Mei 2018 berjumlah 1.351 jiwa, dengan rincian laki-laki 696 jiwa perempuan 655 jiwa dengan $428 \mathrm{KK}$, dengan jumlah tersebut sehingga memungkinkan penduduk untuk melaksanakan kerja sama baik dengan desa lain maupun dengan perusahaan yang ada di sekitar desa Binjai Hilir sehingga penduduk di desa tersebut mengembangkan usaha melalui mata pencaharian perkebunan, itu sebabnya anggota KUD adalah petani yang memiliki kebun sawit.

Namun demikian penduduk desa Binjai Hilir tidak membedakan profesi atau pekerjaan satu dengan lainnya sehingga penduduknya aman dan harmonis serta toleransi yang tinggi. Penduduk dalam melaksanakan pembangunan melalui partisipasi dan gotong-royong serta saling tolongmenolong sehingga masyarakat rukun dan jarang ada persoalan antar warga masyarakatnya, selain itu, penegakan terhadap hukum adat juga masih tinggi semua persoalan yang berkaitan dengan pelanggaran diselesaikan melalui hukum adat atau musyawarah bersama. Berdasarkan kebiasaan gotong-royong masyarakat sehingga memungkinkan pengembangan KUD Salah satu tujuan koperasi yang sangat sederhana bagi anggota adalah meningkatkan kesejahteraan serta memperbaiki ekonomi, dengan demikian banyak harapan yang dilakukan sebagai anggota koperasi, sementara untuk pengurus koperasi dan manajemen juga mengharapkan agar anggota koperasi mengalami peningkatan baik dari segi aset maupun jumlah anggota. Keberhasilan koperasi yang mendasar bukan seberapa besar jumlah aset tetapi seberapa banyak anggotanya, dengan demikian pertumbuhan anggota koperasi menjadi penting. Sejalan dengan hal tersebut sehingga pengurus koperasi berusaha sebaik mungkin dan terus-menerus meningkatkan kinerjanya melalui berbagai strategi.

Strategi yang di gunakan agar anggota semakin bertambah maupun pertumbuhan aset adalah dengan melakukan promosi, promosi yang dimaksud adalah melakukan penjelasan kepada masyarakat yang belum menjadi anggota koperasi sehingga masyarakat menjadi mengerti tentang keberadaan koperasi unit desa yang bertujuan untuk kesejahteraan anggota. Hal ini dilakukan karena masih banyak masyarakat yang belum memahami arti pentingnya KUD bagi masyarakat padahal sesuai dengan tujuan koperasi adalah menguatkan perekonomiam masyarakat. Melalui penjelasan maupun promosi sehingga anggota semakin bertambah dari tahun sebelumnya, dengan bertambahnya anggota maka dengan sendirinya aset juga bertambah.

Dengan demikian, fungsi KUD dapat bermanfaat secara maksimal dalam menguatkan perekonomian masyarakat sehingga peranan koperasi unit desa dapat di rasakan manfaatnya bagi anggota maupun masyarakat, oleh karena itu, koperasi harus dapat mendorong perekonomian masyarakat melalui berbagai program pembinaan maupun program pemberdayaan masyarakat dengan memberikan berbagai macam keterampilan, sesuai kebutuhan masyarakat sehingga hasilnya dapat meningkatkan kesejahteraannya melalui KUD, 
dengan demikian keberadaan koperasi menjadi sangat penting bagi masyarakat sebab melalui koperasi masyarakat dapat mengajukan pinjaman dengan persyaratan yang sangat mudah serta tidak berbelit-belit dan dilakukan pendampingan maupun pembinaan oleh manajemen koperasi sehingga penggunaan uang pinjaman menjadi efektif serta memiliki kegunaan sesuai dengan harapan anggota koperasi. Sejalan dengan peranan dan fungsi koperasi tersebut mengharapkan agar anggota koperasi dapat meningkatkan kesejahteraannya melalui pemahaman tentang manfaat dari koperasi yang bertujuan menjadi penopang ekonomi keluarga dan masyarakat sehingga koperasi dalam rangka tersebut memberikan bimbingan danpendampingan pada anggota agar dapat menggunakan keuangannya dengan sebaik mungkin serta memberikan pembinaan dalam membuka usaha terutama usaha kecil dan menengah kebawah.

Persyaratan yang diperlukan dalam mengajukan pinjaman mengisi formulir pengajuan pinjaman, sudah menjadi anggota koperasi, serta membuat pernyataan mampu mengembalikan pinjaman sesuai dengan ketentuan yang berlaku di koperasi Dharma Bhakti. Selain pinjaman untuk usaha koperasi juga menyediakan bentuk pinjaman umum dalam arti tidak hanya untuk usaha mikro tetapi menyediakan bentuk pinjaman untuk melanjutkan pendidikan baik sekolah menengah maupun Perguruan Tinggi. Dengan demikian, keberadaan koperasi sangat membantu masyarakat sehingga anggota koperasi semakin bertambah baik dari segi aset maupun pertumbuhan anggota dari tahun ke tahun berikutnya. Dengan demikian masyarakat memahami dan mengerti bahwa melalui koperasi ekonomi masyarakat menjadi meningkat tentunya melalui pembinaan karyawan koperasi maupun manejer, oleh karena itu semua unsur atau komponen yang ada harus memainkan fungsi masing-masing Oleh karena itu, maka manajer bertanggungjawab untuk kemajuan koperasi baik dari segi perencanaannya maupun ketepatan pelaksanaan kegiatan koperasi merupakan tanggungjawab manejer serta pengurus koperasi.

Dengan demikian ketepatan waktu pelaksanaan kegiatan maupun penggunaan anggaran merupakan tanggungjawab manajer selaku pimpinan karyawan atau manajemen koperasi, sehingga kinerja manajer di evaluasi oleh pengurus setiap satu tahun sekali untuk melihat sejauhmana perkembangan koperasi, jika tidak sesuai maka manajer menerima berbagai saran dan masukan dari pengurus untuk meningkatkan kinerjanya dalam rangka memajukan koperasi sehingga kemajuannya akan berdampak positif bagi masyarakat terutama anggota koperasi. Selanjutnya pengurus bertanggungjawab atas kebijakan yang dibuat dan ditetapkan, baik bagi anggota maupun bagi pengurus sendiri serta bertanggungjawab atas kelancaran kegiatan usaha yang dikelolanya. Selain itu pengurus bertanggungjawab atas penyelenggaraan rapat anggota termasuk mengembangkan usaha koperasi serta menentukan dan mengendalikan manajemen koperasi melalui manajer koperasi, sebab manejer bertanggung jawab pada pengurus dalam melaksanakan aktifitas maupun pelaksanaan tugas lainnya sesuai kewenangan yang ada pada kebijakan koperasi, oleh karena itu, manajer harus menjadi pengendali dan menentukan arah dan tujuan koperasi dalam rangka meningkatkan kesejahteraan anggota koperasi melalui segala bentuk fasilitas pelayanan yang di sediakan seperti pembagian sisa hasil usaha, peningkatan kepercayaan anggota pada koperasi dan dapat meningkatkan pendapatan selama satu tahun anggaran seiring dengan pelaksanaan rapat anggota tahunan (RAT).

Sesuai dengan tujuan koperasi maka pengurus maupun manajer serta seluruh karyawan harus melakukan berbagai macam program maupun produk yang nantinya dibahas dalam rapat anggota tahunan, tujuan menawarkan berbagai produk adalah untuk meningkatkan usaha koperasi sehingga menjadi lebih baik dari sebelumnya. Selanjutnya dalam menguatkan perekonomian masyarakat melalui usaha koperasi tentunya memerlukan usaha nyata dari koperasi melalui peningkatan keterampilan, melalui program pemberdayaan masyarakat berupa pembinaan usaha maupun keterampilan lainnya. Dengan demikian, Manajer maupun karyawan koperasi berupaya memberikan arahan dan pembinaan pada masyarakat tidak hanya menyalurkan dana pinjaman tetapi mengarahkan manfaat dari pinjaman tersebut agar digunakan tepat sasaran yang diinginkan oleh peminjam (anggota), hal ini dilakukan mengingat tidak semua anggota memiliki keterampilan dan pemahaman tentang pengelolaan keuangan secara tepat, dengan demikian melalui pembinaan dan pendampingan anggota memperoleh pengalaman maupun pengetahuan mengelola keuangan dengan baik, sehingga hasilnya berdampak positif bagi perkembangan penguatan perekonomian masyarakat.

Selanjutnya sesuai dengan fungsi koperasi maka kegiatan koperasi berorientasi pada anggota bukan mengutamakan kesejahteraan lembaga sebab jika lembaga yang lebih di utamakan anggota merasa di abaikan sehingga dapat menyebabkan anggota keluar dari keanggotaan koperasi, hal ini bukan berarti lembaga tidak penting tetapi kesejahteraan anggota harus jadi prioritas, karena anggota sejahtera maka sudah pasti lembaga juga sejahtera, dengan demikian maka koperasi harus berorientasi pada kesejahteraan anggota lebih diutamakan. Anggota koperasi rata-rata adalah petani perkebunan kelapa sawit, anggota koperasi biasanya mengajukan pinjaman sebagai modal awal dalam mengelola kebun sejak pemupukan dan pemeliharaan bagi petani yang memiliki kebun 
pribadi yang berasal dari pembagian perusahaan sifatnya plasma dan itu menjadi hak milik masyarakat (petani) sehingga pinjaman yang di ajukan anggota pada KUD digunakan oleh anggota dengan baik dalam rangka memelihara kebun kelapa sawit. Anggota koperasi merasa terbantu dengan adanya KUD Dharma Bhakti sebab tanpa pemberian pinjaman dari KUD maka kesulitan dalam mengelola kebun dengan baik, karena keterbatasan modal. Selanjutnya anggota koperasi dalam pengembalian pinjaman tidak merasa kesulitan, sebab rata-rata kebun kelapa sawit sudah panen dan sudah menghasilkan serta dapat membantu perekonomian anggota koperasi. Dengan demikian, peranan KUD sangat membantu anggota dalam mengembangkan usahanya sehingga pengelolaan keuangan tergantung pada individu anggota masing-masing berhasil atau tidak.

Sejalan dengan hal tersebut di atas, agar anggota koperasi dapat menggunakan keuangan dengan baik maka selalu di berikan bimbingan dan arahan dari pengurus maupun manajer koperasi baik pada saat melakukan pinjaman maupun pada saat mengembalikan pinjaman sehingga penggunaannya dapat efektif sesuai dengan yang telah di rencanakan anggota. Bimbingan atau pendamping dalam melakukan usaha dari KUD sangat penting sebagai petunjuk arah bagi anggota dalam menjalankan usahanya, sebab tanpa bimbingan dan dukungan dari KUD maka mengalami kesulitan dalam mengelola keuangan, itulah sebabnya koperasi dalam mendidik anggota dimulai dengan pendidikan di kelola dengan pendidikan, tujuannya adalah agar anggota lebih bijak dan cerdas dalam mengelola keuangan, dengan demikian melalui informasi yang diberikan bermanfaat bagi anggota. KUD Dharma Bhakti semakin bertambah anggotanya dari tahun sebelumnya, hal ini di sebabkan karena masyarakat memahami fungsi dari koperasi sehingga pengurus koperasi harus memiliki komitmen dalam mengembangkan koperasi, sebab koperasi sebagai penopang ekonomi masyarakat, fungsinya di rasakan manfaatnya oleh masyarakat.

Selanjutnya bahwa kegiatan KUD Dharma Bhakti selain berorientasi pada kesejahteraan anggota, koperasi juga melakukan kegiatan-kegiatan sosial bekerjasama dengan perusahaan yang ada di sekitar koperasi atau di desa Binjai Hilir, kegiatan sosial yang dilakukan berupa perbaikan jalan desa dengan menggunakan anggaran koperasi melalui dana sosial koperasi yang memang dianggarkan setiap satu tahun buku, perbaikan jalan tersebut bertujuan sebagai penguatan infrastruktur jalan yang merupakan kebutuhan dasar masyarakat dalam memasarkan hasil perkebunan maupun hasil pertanian khususnya sawit melalui KUD sebab hasil perkebunan kelapa sawit tidak dapat di jual di sembarang tempat terkecuali pengusaha yang memiliki kerja sama dengan koperasi atau perusahaan yang ada di sekitar perkebunan kelapa sawit, komunikasi anggota dengan KUD dilakukan dua arah sebagai bentuk pembinaan koperasi pada anggota khususnya dalam pengelolaan keuangan anggota melalui pengarahan yang dilakukan oleh manajemen koperasi. Selain itu adanya kesatuan kerja sama antara menejer dengan karyawan. Oleh karena itu, koordinasi kerja dalam melaksanakan kegiatan atau aktifitas koperasi sangat diperlukan sebagai bentuk adanya kesamaan tujuan serta komitmen yang sama dalam memajukan koperasi terutama anggota koperasi sebab koperasi tidak akan maju tanpa didukung oleh anggota, semakin sejahtera anggota koperasi semakin meningkat sisa hasil usaha koperasi.

Dengan adanya koperasi taraf hidup masyarakat dapat meningkat baik dari segi perekonomian, sosial dan budaya, dari segi perekonomian diharapkan pendapatan masyarakat dapat meningkat, sementara dari segi social diharapkan masyarakat dapat mengembangkan potensi dan kemampuan untuk saling bekerjasama dengan orang lain sedangkan dari segi budaya masyarakat dapat menjaga budaya nasional dengan cara melakukan usaha bersama atas asas kekeluargaan. Namun demikian koperasi yang ada saat ini belum mampu menyentuh kehidupan seluruh masyarakat pada umumnya masyarakat desa pada khususnya, koperasi hanya dapat diniikmati oleh orang-orang yang sudah menjadi anggota serta memiliki kesadaran berpartisipasi tinggi, sementara anggota yang tidak aktif dalam kegiatan perkoperasian juga belum dapat menggunakan koperasi dengan baik dalam memenuhi kebutuhannya. Selanjutnya KUD dapat juga berfungsi sebagai koperasi serba usaha artinya bahwa koperasi unit desa dapat menjual berbagai macam barang khususnya kebutuhan pertanian dan tidak hanya menjual alat-alat atau bahan pertanian saja. Dengan demikian, KUD harus dapat berfungsi menyalurkan sarana produksi dan menjadi penyalur hasil pertanian, oleh karena itu, KUD Dharma Bhakti memberikan bimbingan teknis pada anggota koperasi serta memberikan penyuluhan pada masyarakat dalam mengembangkan ekonomi masyarakat sehingga masyarakat menjadi terampil dalam menjalankan usaha serta dapat meningkatkan perekonomian masyarakat yang ada di wilayah pedesaan. Peranan koperasi menjadi harapan bagi masyarakat agar dapat mengembangkan potensi melalui pemberdayaan, pembinaan serta penyuluhan pada masyarakat dalam rangka meningkatkan perekonomian melalui keterampilan berupa bimbingan teknis dari KUD. 
Namun demikian bahwa bimbingan yang di berikan oleh koperasi khususnya Koperasi Unit Desa (KUD) masih terkendala oleh kurangnya sumber daya manusia yang terampil khususnya dalam pengelolaan dibidang pertanian, pembinaan dan penyuluhan yang dilakukan oleh koperasi tentu belum dapat dilakukan secara maksimal hal ini di sebabkan terbatasnya sumber daya manusia khususnya dibidang pertanian sementara karyawan yang ada lebih banyak mengurus kegiatan yang berkaitan dengan kegiatan ketatausahaan, manajer koperasi mengakui kekurangan sumber daya manusia khususnya dibidang pertanian bukan berarti bahwa karyawan koperasi tidak melakukan pembinaan, pembinaan tetap di berikan sebagai bentuk bimbingan teknis dalam pengelolaan keuangan seperti pentunjuk penggunaan keuangan yang tepat guna. Selain itu dalam melakukan pembinaan tetap selalu ada koordinasi yang sinkron dan teratur untuk menyediakan jumlah dan waktu yang tepat, dan mengarahkan pelaksanaan untuk menghasilkan suatu tindakan dalam rangka pembinaan keterampilan pada masyarakat. Pemberdayaan masyarakat yang dimaksud adalah pembinaan bimbingan teknis pada anggota koperasi dalam pengelolaan keuangan yang tepat sasaran, hal ini dilakukan oleh koperasi dengan mengumpulkan anggota untuk melakukan pengarahan, penyuluhan tentang strategi mengatur penggunaan keuangan yang efisien tanpa adanya pemborosan. Tindakan ini dilakukan secara terus menerus oleh KUD dalam hal ini karyawan koperasi setiap tiga bulan sekali sementara bimbingan teknis dilapangan khususnya dibidang pertanian bekerjasama dengan PPL sesuai dengan kebutuhan petani yang perlu bimbingan teknis.

\section{KESIMPULAN DAN SARAN}

Anggota koperasi merasa terbantu dengan adanya KUD Dharma Bhakti sebab tanpa pemberian pinjaman dari KUD maka kesulitan dalam mengelola usahanya dengan baik, koperasi sebagai pemberi modal usaha bagi anggota bertujuan meningkatkan kemampuan anggota dibidang perekonomian. Koperasi sebagai sarana kesejahteraan masyarakat, melakukan pembinaan dan penyuluhan serta pendampingan kepada anggota serta peningkatan keterampilan, dalam memberikan bimbingan teknis serta memberikan arahan dalam menggunakan keuangan sehingga menjadi efektif sesuai keinginan anggota dalam meningkatkan pendapatannya, namun demikian kegiatan ini belum rutin dilakukan mengingat keterbatasan karyawan KUD. Bimbingan yang di berikan oleh koperasi khususnya Koperasi Unit Desa (KUD) masih terkendala oleh kurangnya sumber daya manusia yang terampil khususnya dalam pengelolaan usaha terutama dibidang pertanian, sehingga KUD bekerja sama dengan penyuluh pertanian lapangan (PPL), Sesuai dengan hasil penelitian dan pembahasan serta kesimpulan penelitian maka saran yang dapat penulis ajukan : Koperasi sebagai pemberi modal pinjaman sebaiknya memberikan bimbingan dan pendampingan yang lebih baik lagi diharapkan pemberian pinjaman pada anggota agar tepat sasaran perlu pengarahan dan petunjuk pengelolaan keuangan. Pemberdayaan anggota menjadi faktor penting dalam pengembangan koperasi sehingga perlu adanya tenaga yang terampil dalam pendampingan pada anggota, sehingga KUD tidak hanya mengandalkan kemitraan dengan pihak lain dalam meningkatkan pemberdayaan anggota.

\section{DAFTAR PUSTAKA}

Anggara, Sahya. 2015. Metode Penelitian Administrasi. Bandung : Pustaka Setia

Budiman, A. 2002.Pemberdayaan Perempuan dan Perannya Dalam Pembangunan. Jakarta : Jurnal PPSK

Boediono. 2015. Kamus Lengkap Bahasa Indonesia. Jakarta : Bintang Indonesia

Feryanto, Agung. 2010. Ekonomi Program Ilmu Sosial. Klaten : PT. Intan Pariwara.

Faisal, S. 2001. Format-format Penelitian Sosial. Jakarta : Raja Grafindo Persada

Gie, T.L. 2005. Administrasi Perkantoran Modern. Yogyakarta : Liberty.

Handoko.T. 2002. Manajemen Sumber Daya Manusia. Jakarta: Rineka Cipta.

Handayani. 1999. Pembangunan Wanita Indonesia dan Pemberdayaan. Jakarta : Fokusmedia.

Kartiwa. A. 2015. Metode Penelitian Administrasi. Bandung: Pustaka Setia

Mubyarto, 1984. Strategi Pembangunan Pedesaan. Yogyakarta: P3PK UGM

Manullang, M. 2005. Dasar-Dasar Manajemen. Yogyakarta: Gajah Mada University Press.

Ndraha, T. 1987. Pembangunan Masyarakat Menpersiapkan Masyarakat Tinggal Landas. Jakarta: Bina Aksara.

Nasution, Muslimin, (2001). Koperasi, Konsepsi Pemikiran dan Peluang PembangunanMasa Depan Bangsa. Jakarta: Badan Perencanaan Pembangunan Nasional.

Nasution, S.2001. Metode Penelitian Naturalistik Kualitatif. PT. Remaja Rosdakarya

Robin, S. 1996. Prilaku Organisasi. Jakarta : Prenhallindo.

Rudianto.2006. Akuntansi Koperasi. Jakarta : Grafindo Persada.

Sastraatmaja, Entang. 2005. Ekonomi dan Pembangunan. Bandung : ARMICO 
Santoso, Ananda. 2015. Kamus Lengkap Bahasa Indonesia. Surabaya :Dara Publika

Surya Dharma Ali, (2007). Komitmen Pemberdayaan UMKM dan Koperasi.

Disampaikan pada Seminar Prospek Usaha Kecil dan Menengah, Lembaga U s a h a Pengembangan Masyarakat Jakarta.

Peraturan Perundangan:
Peraturan Pemerintah RI No. 9 Tahun 1995 Tentang Pelaksanaan Kegiatan Simpan Pinjam oleh Koperasi; Penerbit Departemen Koperasi dan Pembinaan Pengusaha Kecil, Jakarta.

Undang-Undang Nomor 25 Tahun 1992 tentang Perkoperasi. Jakarta:Penerbit BK3I.

Undang - Undang Nomor 6 Tahun 2014 Tentang Desa 